\title{
ANALISIS FAKTOR - FAKTOR YANG MEMPENGARUHI KEBERHASILAN USAHA KECIL DAN MENENGAH PADA PENGRAJIN TENUN SONGKET DI DESA JINENGDALEM KECAMATAN BULELENG
}

\author{
Ni Made Diah Anggraeni \\ Program Studi Pendidikan Ekonomi, Fakultas Ekonomi \\ Universitas Pendidikan Ganesha \\ Singaraja, Indonesia
}

email :anggraenii diah@yahoo.com

\begin{abstract}
ABSTRAK
Penelitian ini bertujuan untuk mengetahui (1) faktor-faktor yang mempengaruhi keberhasilan usaha kecil dan menengah pada pengrajin tenun songket di Desa Jinengdalem Kecamatan Buleleng dan (2) faktor yang paling dominan mempengaruhi keberhasilan usaha kecil dan menengah pada pengrajin tenun songket di Desa Jinengdalem Kecamatan Buleleng. Jenis penelitian ini merupakan penelitian faktorial. Teknik analisis data yang digunakan dalam penelitian ini adalah analisis faktor. Hasil penelitian menunjukkan, (1) terdapat empat faktor yang mempengaruhi keberhasilan usaha kecil dan menengah pada pengrajin tenun songket di Desa Jinengdalem Kecamatan Buleleng, yaitu motivasi, usia, pengalaman, dan pendidikan. Besarnya variance explained faktor secara berturut-turut, yaitu motivasi sebesar $49,106 \%$, usia sebesar $27,430 \%$, pengalaman sebesar $13,705 \%$, dan pendidikan sebesar $9,758 \%$. (2) faktor yang paling dominan mempengaruhi keberhasilan usaha kecil dan menengah pada pengrajin tenun songket di Desa Jinengdalem Kecamatan Buleleng yaitu motivasi memiliki variance explained sebesar $49,106 \%$, artinya total nilai variance explained dari motivasi mampu menjelaskan keberhasilan usaha kecil dan menengah pada pengrajin tenun songket di Desa Jinengdalem Kecamatan Buleleng.
\end{abstract}

Kata kunci : keberhasilan usaha, pengrajin, tenun songket.

\section{ABSTRACT}

Research aims to know the (1) factors affect the success of small and medium business in craftsman songket woven in the Jinengdalem village in Buleleng district and ( 2 ) the most dominant affect the success of small and medium business in craftsman songket weaving in the Jinengdalem village in Buleleng district. The kind of this research is factorials. the techniques used of this research is factor analysis. The results of this research show, ( 1 ) there are four factors affect the success of small and medium business in craftsman songket woven in the Jinengdalem village Buleleng district, that is motivation, age , experience , and education. The variance explained factor in a row, the motivation of $49,106 \%$, age of $27,430 \%$, experience of $13,705 \%$, and education of $9,758 \%$. ( 2 ) the most dominant affect the success of small and medium business at craftsman songket weaving in the Jinengdalem village Buleleng district is motivation having variance explained by $49,106 \%$, this means that the total value of variance explained of motivation be able to explain the success of small and medium business at craftsman songket weaving in the Jinengdalem village in Buleleng district.

Keywords : business success, craftsman, songket weaving. 


\section{PENDAHULUAN}

Minimnya lapangan pekerjaan saat ini mendorong orang-orang untuk membuka usaha sendiri atau yang sering disebut dengan berwirausaha. Dimana usaha yang belakangan ini mendominasi adalah usaha kecil dan menengah. Usaha ini dipilih karena memiliki fleksibilitas dan kemampuan dalam menyesuaikan diri terhadap kondisi pasar yang berubah-ubah dengan cepat dibandingkan dengan perusahaan yang berskala besar yang umunya bersifat birokratis.

Usaha kecil adalah kegiatan ekonomi rakyat yang berskala kecil, dan memenuhi kekayaan bersih atau hasil penjualan tahunan serta kepemilikan sebagaimana diatur dalam Undang Undang Nomor 20 Tahun 2008 tentang Usaha Mikro, Kecil, dan Menengah (UU UMKM). Usaha Kecil adalah usaha ekonomi produktif yang berdiri sendiri, yang dilakukan oleh orang perorangan atau badan usaha yang bukan merupakan anak perusahaan atau bukan cabang perusahaan yang dimiliki, dikuasai, atau menjadi bagian baik langsung maupun tidak langsung dari usaha menengah atau usaha besar yang memenuhi kriteria usaha kecil sebagaimana dimaksud dalam UU UMKM. Usaha kecil memiliki kekayaan bersih lebih dari Rp. 50.000.000 (lima puluh juta rupiah) sampai dengan $\mathrm{Rp}$. 500.000 .000 (lima ratus juta rupiah), tidak termasuk tanah dan bangunan tempat usaha atau memiliki hasil penjualan tahunan lebih dari $\mathrm{Rp}$. 300.000 .000 (tiga ratus juta rupiah) sampai dengan Rp. 2.500.000.000 (dua milyar lima ratus juta rupiah).

Kesuksesan suatu usaha pada dasarnya tidak tergantung pada besar kecilnya ukuran usaha, tetapi lebih dipengaruhi oleh bagaimana mengelolanya dan pelaku usaha juga harus pandai melihat peluang yang ada. Seperti yang kita ketahui bahwa keberhasilan tidak mungkin diraih dengan begitu saja, tetapi harus melalui beberapa tahapan. Untuk menjadi wirausaha yang sukses harus memiliki ide atau visi bisnis yang jelas, kemudia ada kemauan dan keberanian untuk menghadapi risiko baik waktu maupun uang. Langkah selanjutnya yang sangat penting adalah dengan membuat perencanaan usaha, pengorganisasian, dan menjalankanya (Suryana,2011). Keberhasilan usaha pada hakikatnya adalah keberhasilan dari bisnis mencapai tujuannya, suatu bisnis dikatakan berhasil apabila mendapat laba, karena laba adalah tujuan dari orang melakukan bisnis (Henry,2007). Suatu usaha dikatakan berhasil apabila setelah jangka waktu tertentu usahanya mengalami peningkatan baik dalam permodalan, skala usaha, hasil atau laba, jenis usaha atau pengelolaan (Erliah,2007). Keberhasilan usaha adalah permodalan sudah terpenuhi, penyaluran produktif dan tercapainya tujuan organisasi (Primiana, 2009). Laba merupakan faktor tujuan yang kritis dan menjadi ukuran dari keberhasilan suatu usaha (Albert dalam Suryana, 2011). Usaha kecil berhasil karena wirausaha memiliki otak yang cerdas, kreatif, mengikuti perkembangan teknologi dan dapat menerapkan secara proaktif. Mereka juga memiliki energi yang melimpah serta dorongan dan kemampuan asertif (Riyanti, 2003).

Berdasarkan beberapa pendapat diatas, maka dapat disimpulkan bahwa keberhasilan usaha adalah keberhasilan dari bisnis mencapai tujuannya, dimana keberhasilan tersebut didapatkan dari seorang wirausaha yang memiliki otak cerdas, kreatif, mengikuti perkembangan teknologi dan dapat menerapkannya secara proaktif dan hal tersebut terlihat dari usaha seseorang dimana suatu keadaan usahanya yang lebih baik dari periode sebelumnya, dapat dilihat dari efisiensi proses 
produksi yang dikelompokkan berdasarkan efisiensi secara teknis dan efisiensi secara ekonomis, target perusahaan yang ditentukan oleh pemilik usaha, permodalan, skala usaha, hasil atau laba, jenis usaha atau pengelolaan, kinerja keuangan, serta image perusahaan.

Keberhasilan dalam menjalani usaha merupakan dambaan bagi semua pelaku usaha, sehingga akan melakukan apa saja untuk mencapainya. Dalam mencapai keberhasilan tersebut perlu diketahui faktor apa saja yang dapat mempengaruhinya. Keberhasilan usaha dipengaruhi oleh empat faktor yaitu (1) motivasi, (2) usia, (3) pengalaman, (4) pendidikan (Basrowi,2011). Motivasi timbul dari diri sendiri untuk mencapai suatu tujuan tertentu dan juga bisa dikarenakan oleh dorongan orang lain. Tetapi motivasi yang paling baik adalah dari diri sendiri karena dilakukan tanpa paksaan dan setiap individu memiliki motivasi yang berbeda untuk mencapai tujuannya. Mengukur motivasi dapat dilihat dari; dorongan mencapai tujuan, semangat kerja, inisiatif dan kreatifitas, rasa tanggungjawab (Syahyuti,2010). Usia ,semakin tinggi usia seseorang, maka semakin bertambah pula ilmu atau pengetahuan yang dimiliki karena pengetahuan seseorang diperoleh dari pengalaman sendiri maupun pengalaman yang diperoleh dari orang lain (Notoatmodjo,2003). Menurut Moekijad (1992) usia yag dimiliki oleh pekerja sangat berpengaruh dalam menjalankan aktivitas kerjanya. Menurut Amron (2009) usia seseorang dapat menentukan keberhasilan dalam melakukan suatu pekerjaan. Untuk mengukur usia pekerja dapat dilihat dari: usia produktif, dan usia tidak produktif. Pengalaman adalah pengetahuan atau ketrampilan yang telah dikuasai oleh seseorang akibat dari pekerjaan yang telah dilakukan selama beberapa waktu tertentu. Pengalaman mengelola usaha juga dapat diperoleh dari pengasuhan yang diberikan oleh orang tua yang berprofesi sebagai wirausaha. Handoko (2004) menyatakan "semakin luas pengalaman kerja seseorang, semakin terampil seseorang dalam bertindak untuk mencapai tujuan yang telah ditetapkan". Untuk mengukur pengalaman seseorang dapat dilihat dari; lama waktu atau masa kerja, pengetahuan dan keterampilan, dan penguasaan terhadap pekerjaan. Pendidikan adalah usaha yang dijalankan seseorang atau kelompok orang lain agar menjadi dewasa atau mencapai tingkat hidup atau penghidupan yang lebih tinggi (Hasbullah, 2009). Pendidikan dapat diukur melalui (1) pendidikan formal dilihat dari pendidikan yang didapat dibangku sekolah, (2) pendidikan non formal dilihat dari pelatihan - pelatihan yang pernah diikuti.

Menjalani sebuah usaha tidak akan terlepas dari adanya permasalahan atau penghambat dalam sebuah usaha. Adapun permasalahan yang biasa dihadapi oleh usaha kecil menengah antara lain faktor internal seperti (1) kurangnya permodalan, (2) sumber daya manusia yang terbatas, (3) lemahnya jaringan usaha dan kemampuan penetrasi pasar. Faktor eksternal seperti (1) iklim usaha yang belum sepenuhnya kondusif, (2) terbatasnya sarana dan prasarana usaha, (3) implikasi otonomi daerah, (4) implikasi perdagangan bebas, (4) sifat produk dengan lefttime pendek, (5) terbatasnya akses pasar.

Di Desa Jinengdalem usaha kerajinan memiliki pengaruh di dalam menunjang perekonomian masyarakat, selain sektor pertanian dan perkebunan. Dengan demikian, sektor kerajinan sampai sekarang masih tetap diusahakan sebagai mata pencaharian bagi masyarakat di Desa Jinengdalem. Desa Jinengdalem sebagai salah satu sentra industri, khususnya industri dalam hal kerajinan tradisional yaitu tenun songket yang berkembang secara turun temurun. Menurut Tohar (2001), usaha kecil tradisional adalah usaha yang menggunakan alat produksi sederhana yang telah digunakan secara turun temurun, dan atau berkaitan dengan seni budaya. Pada mulanya, tenun songket yang merupakan tenun tradisional dibuat khusus untuk 
konsumsi sendiri. Seiring dengan perkembangan jaman, tenun songket mengalami perkembangan dari segi pemanfaatannya sehingga dijadikan salah satu komoditi usaha yang dapat menciptakan lapangan pekerjaan baru bagi masyarakat di Desa Jinengdalem.

Dalam menjalani usahanya selama ini para pengrajin mendapat banyak dukungan dari berbagai pihak baik dari desa Jinengdalem bahkan dari kabupaten Buleleng. Pada tahun 2014 Dinas Koperasi, Perindustrian, dan Perdagangan memberikan penyuluhan kepada pengrajin mengenai cara mengelola usaha. Pendidikan ini diberikan pada pengrajin agar dapat diterapkan dalam menjalani usahanya, selain memberikan penyuluan para pengrajin juga diberi bantuan berupa cag - cag yaitu alat yang digunakan pengrajin untuk menenun.

Berdasarkan hasil penelitian awal yang dilakukan pada sentra kerajinan tenun songket di Desa Jinengdalem yang sekarang pada tahun 2016 berjumlah 67 pengrajin yang tersebar di Desa Jinengdalem. Dari 67 pengrajin yang masih bertahan, 38 pengrajin dapat dikategorikan sebagai pengrajin yang berhasil. Keberhasilan usaha dapat dilihat dari adanya peningkatan permodalan, pendapatan, output produksi, volume penjualan, dan tenaga kerja (Suryana,2003). Dilihat dari aspek tersebut 38 pengerajin ini mengalami peningkatan dalam permodalan, pendapatan, output produksi, dan volume penjualan. Dilihat dari aspek tenaga kerja walaupun tidak mengalami penambahan pekerja setiap tahunnya, hal ini dikarenakan dalam proses produksi jumlah tenaga kerja yang tersedia masih mampu dan efektif dalam menyelesaikan pekerjaan tepat waktu dengan kualitas yang sama tanpa adanya tenaga kerja tamabahan. Melihat sedikitnya jumlah pengrajin yang berhasil, maka penulis tertarik untuk meneliti mengenai faktor - faktor apa saja yang mempengaruhi keberhasilan usaha kecil dan menengah pada pengrajin tenun songket di Desa Jinengdalem tersebut.
Dari latar belakang yang telah diuraikan, maka dapat dirumuskan masalah sebagai berikut, (1) faktor faktor apa saja yang mempengaruhi keberhasilan usaha kecil dan menengah pada pengrajin tenun songket di Desa Jinengdalem Kecamatan Buleleng?, (2) faktor mana yang paling dominan mempengaruhi keberhasilan usaha kecil dan menengah pada pengrajin tenun songket di Desa Jinengdalem Kecamatan Buleleng?

Meninjau dari permasalahan yang ada maka tujuan penelitian ini adalah, (a) untuk mengetahui faktor-faktor yang mempengaruhi keberhasilan usaha kecil dan menengah pada pengrajin tenun songket di Desa Jinengdalem Kecamatan Buleleng, (b) untuk mengetahui faktor dominan yang mempengaruhi keberhasilan usaha kecil dan menengah pada pengrajin tenun songket di Desa Jinengdalem Kecamatan Buleleng.

Manfaat dari penelitian ini adalah (1) manfaat teoritis diharapkan dapat memberikan sumbangan dalam pengembangan ilmu kewirausahaan khususnya dalam bidang keberhasilan usaha sehingga dapat meningkatkan kualitas lulusan perguruan tinggi yang nantinya diharapkan mampu untuk membuka lapangan pekerjaan dalam menghadapi masalah pengangguran. (2) manfaat praktis (a) Bagi Lembaga Undiksha Hasil penelitian ini diharapkan dapat menjadi tambahan referensi bagi mahasiswa yang akan meneliti lebih lanjut. (b) Bagi Pengrajin hasil penelitian ini diharapkan dapat membantu memberikan sumbangan pemikiran dalam mendukung keberhasilan dalam pelaksanaan usaha.

\section{METODE}

Penelitian ini merupakan penelitian faktorial, dan data dalam penelitian ini akan dianalisis dengan menggunakan analisis faktor, dalam penelitian analisis faktor hubungan antar variabel tersebut saling ketergantungan (interdependence) sehingga tidak ada pembagian variabel bebas dan variabel 
terikat, sedangkan metode penelitian yang digunakan adalah metode survei. Penelitian ini diharapkan menunjukan hasil dari faktor-faktor apa saja yang mempengaruhi keberhasilan usaha pengrajin tenun songket di desa Jinengdalem.

Populasi yang digunakan dalam penelitian ini adalah pengrajin tenun songket di Desa Jinengdalem yang berhasil menjalankan usahanya dilihat dari aspek permodalan, pendapatan, output usaha, volume penjualan, dan tenaga kerja sebanyak 38 orang.

Mengingat jumlah populasi yang kurang dari 100 maka seluruh populasi diambil untuk dijadikan sampel.

Jenis data yang digunakan dalam penelitian ini adalah data kualitatif dan data kuantitatif. Data kualitatif berupa data yang tidak dapat diukur dan dihitung, tetapi dapat memberikan informasi bagi peneliti, sedangkan data kuantitatif data berupa angka yang diperoleh melalui kuisioner mengenai keberhasilan usaha kecil dan menengah pada pengrajin tenun songket di Desa Jinengdalem Kecamatan Buleleng.

Sumber data yang digunakan dalam penelitian ini adalah data primer dan data sekunder. Data primer dalam penelitian ini berupa skor hasil kuesioner tentang keberhasilan usaha pengrajin tenun songket di Desa Jinengdalem melalui penyebaran kueisoner yang diberikan kepada pengrajin tenun songket di Desa Jinengdalem sebagai responden. Data sekunder dalam penelitian ini yaitu data mengenai jumlah pengrajin tenun songket di Desa Jinengdalem Kecamatan Buleleng.

Metode pengumpulan data yang digunakan dalam penelitian ini menggunakan kuesioner. Kuesioner dipergunakan untuk memperoleh informasi yang relevan dengan tujuan penelitian. Penyebaran kuisioner dilakukan dengan cara memberikan sejumlah pertanyaan yang berkaitan dengan masalah penelitian kepada pengrajin tenun songket di Desa Jinengdalem, sehingga data yang diperoleh yaitu mengenai analisis faktorfaktor yang mempengaruhi keberhasilan usaha pengrajin tenun songket di Desa Jinengdalem Kecamatan Buleleng.

\section{HASIL DAN PEMBAHASAN HASIL}

Data yang berhasil dikumpulkan dari kuesioner yang disebarkan dan setelah diolah dengan SPSS 16.0 for Windows menunjukkan faktor-faktor yang mempengaruhi keberhasilan usaha kecil dan menengah pada pengrajin tenun songket di Desa Jinengdalem Kecamatan Buleleng dapat dijelaskan oleh persentase dari masing-masing faktor. Nilai total Variance explained digunakan untuk mengetahui persentase dari empat faktor yang dianalisis. Hasil analisis faktor melalui SPSS menunjukkan persentase dari masingmasing faktor dapat dilihat pada Tabel 1.

\section{Tabel 1. Total Variance Explained}

\begin{tabular}{|c|c|c|c|c|c|c|c|c|c|}
\hline \multirow{2}{*}{$\begin{array}{l}\text { Com - } \\
\text { pone } \\
\text { nt }\end{array}$} & \multicolumn{3}{|c|}{ Initial Eigenvalues } & \multicolumn{3}{|c|}{$\begin{array}{c}\text { Extraction Sums of Squared } \\
\text { Loadings }\end{array}$} & \multicolumn{3}{|c|}{$\begin{array}{l}\text { Rotation Sums of } \\
\text { Squared Loadings }\end{array}$} \\
\hline & Total & $\begin{array}{c}\% \text { of } \\
\text { Variance }\end{array}$ & $\begin{array}{l}\text { Cumulativ } \\
\text { e \% }\end{array}$ & Total & $\begin{array}{c}\% \text { of } \\
\text { Variance }\end{array}$ & $\begin{array}{l}\text { Cumulativ } \\
\text { e \% }\end{array}$ & Total & $\begin{array}{c}\% \text { of } \\
\text { Variance }\end{array}$ & $\begin{array}{l}\text { Cumula } \\
\text { tive } \%\end{array}$ \\
\hline 1 & 1.964 & 49.106 & 49.106 & 1.964 & 49.106 & 49.106 & 1.954 & 48.839 & 48.839 \\
\hline 2 & 1.097 & 27.430 & 76.536 & 1.097 & 27.430 & 76.536 & 1.108 & 27.697 & 76.536 \\
\hline 3 & .548 & 13.705 & 90.242 & & & & & & \\
\hline 4 & .390 & 9.758 & 100.000 & & & & & & \\
\hline
\end{tabular}


Berdasarkan tabel 1 dapat dilihat bahwa (1) motivasi memiliki eigenvalue sebesar 1,964 dengan nilai varian sebesar 49,106\%, (2) faktor usia memiliki eigenvalue sebesar 1,097 dengan nilai varian sebesar $27,430 \%$, (3) faktor pengalaman memiliki eigenvalue sebesar 0,548 dengan nilai varian sebesar $13,705 \%$, dan (4) faktor pendidikan memiliki eigenvalue sebesar 0,390 dengan nilai varian sebesar $9,758 \%$.

Untuk menjelaskan keberhasilan usaha kecil dan menengah pada pengrajin tenun songket di Desa Jinengdalem Kecamatan Buleleng, dapat dilakukan dengan ekstraksi faktor.
Ekstraksi faktor dapat dijelaskan oleh total persentase dari masing-masing faktor utama.

Faktor-faktor utama tersebut adalah faktor motivasi, dan usia yang memiliki nilai parameter eigenvalue $>1$. Untuk mengetahui distribusi dimensidimensi yang belum dirotasi kedalam faktor yang telah terbentuk maka dapat dilihat pada output SPSS 16.0 (Rotated Component Matrix).

Faktor yang mampu menjelaskan keberhasilan usaha kecil dan menengah pada pengrajin tenun songket di Desa Jinengdalem Kecamatan Buleleng, dapat dilihat pada Tabel 2.

Tabel 2. Faktor yang Menjelaskan Keberhasilan Usaha Kecil dan Menengah pada Pengrajin Tenun Songket di Desa Jinengdalem Kecamatan Buleleng

\begin{tabular}{lccc}
\hline \multicolumn{1}{c}{ Faktor } & Eigenvalue & Variance Explained (\%) & Faktor Loading \\
\hline Motivasi & 1,964 & 49,106 & 0,801 \\
\hline Usia & 1,097 & 27,430 & 0,966 \\
\hline Pengalaman & 0,548 & 13,705 & 0,859 \\
\hline Pendidikan & 0,390 & 9,758 & 0,757
\end{tabular}

Berdasarkan dari Tabel 2, dapat dijelaskan bahwa faktor yang memiliki eigenvalue > 1 adalah fakor motivasi, dan usia total nilai variance explained dari kedua faktor keseluruhan mampu menjelaskan sebesar $76,536 \%$, dengan demikian $76,536 \%$ dari seluruh faktor yang ada, dapat dijelaskan oleh kedua faktor yang terbentuk. Motivasi memiliki variance explained $49,106 \%$, artinya bahwa motivasi mampu mempengaruhi keberhasilan usaha sebesar 49,106\%. Usia memiliki variance explained $27,430 \%$, artinya usia mempengaruhi keberhasilan usaha sebesar $27,430 \%$. Menentukan nama faktor yang telah terbentuk untuk masing-masing faktor bersifat subjektif, kadangkala variabel yang memiliki nilai faktor loading tertinggi digunakan untuk memberi nama faktor. Untuk melihat nilai faktor loading dapat dilihat pada Tabel 3 .

Tabel 3. Rotated Component Matrix

\begin{tabular}{lrr}
\hline & \multicolumn{3}{c}{ Component } \\
\cline { 2 - 4 } & 1 & 2 \\
\hline Pengalaman & .859 & -.145 \\
\hline Motivasi & .801 & -.051 \\
\hline Pendidikan & .757 & .390 \\
\hline Usia & -.035 & .966
\end{tabular}

Bedasarkan Tabel 3, faktor yang mempengaruhi keberhasilan usaha kecil dan menengah pada pengrajin tenun dapat dikelompokkan menjadi 2 (dua) faktor. Masing-masing kelompok faktor tersebut memiliki faktor loading tertinggi di setiap komponen yaitu faktor satu 
terbentuk dari factor. Faktor 1 (satu) terbentuk dari faktor pengalama dengan faktor loading sebesar 0,859 , faktor motivasi dengan faktor loading sebesar 0,801 , dan faktor pendidikan dengan faktor loading sebesar 0,757. Faktor 2 (dua) terbentuk dari faktor usia dengan faktor loading sebesar 0,966.. Kemudian untuk menentukan dimensi faktor yang paling dominan mempengaruhi keberhasilan usaha kecil dan menengah pada pengrajin tenun songket di Desa Jinengdalem, digunakan parameter koefesien varimax atau mendekati 1 atau mendekati -1 . Nilai yang mendekati 1 diawali oleh nilai 0,50 sedangkan nilai yang mendekati -1 diawali oleh $-0,50$. Secara lebih rinci hasil ringkasan rotasi dari matriks faktor memuat nilai varimax rotation, dapat dilihat pada tabel 4 .

Tabel 4. Matriks Rotasi Hasil Anallisis Faktor

\begin{tabular}{lcc}
\hline \multicolumn{1}{c}{ Faktor keberhasilan usaha kecil dan } & \multicolumn{2}{c}{ Varimax Rotation (\%) } \\
\cline { 2 - 3 } menengah pada pengrajin tenun songket & $(1)$ & $(2)$ \\
\hline Motivasi & 49,106 & - \\
\hline Usia & - & 27,430 \\
\hline
\end{tabular}

Berdasarkan tabel 4, maka faktor yang paling dominan mempengaruhi keberhasilan usaha kecil dan menengah pada pengrajin tenun songket di Desa Jinengdalem Kecamatan Buleleng adalah faktor motivasi dengan nilai varimax rotation $49,106 \%$. Artinya kejelasan dari dimensi atau faktor keberhasilan usaha kecil dan menengah pada pengrajin tenun songket adalah motivasi yang paling mendominasi sebesar $49,106 \%$.

\section{PEMBAHASAN}

Berdasarkan hasil penelitian yang diperoleh mengenai faktor - faktor yang mempengaruhi keberhasilan usaha kecil dan menengah pada pengrajin tenun songket di Desa Jinengdalem Kecamatan Buleleng dipengaruhi oleh faktor motivasi, usia, pengalaman, dan pendidikan. Hal ini sesuai dengan teori Basrowi (2011), bahwa faktor yang mempengaruhi keberhasilan usaha adalah motivasi, usia, pengalaman, dan pendidikan. Dengan demikian untuk menjelaskan faktor yang mempengaruhi keberhasilan usaha kecil dan menengah pada pengrajin tenun songket di Desa Jinengdalem Kecamatan Buleleng, dapat dilihat dari faktor - faktor yang meniliki eigenvalue $>1$ yaitu, faktor motivasi dan faktor usia.

Faktor motivasi dan usia merupakan faktor yang dominan mempengaruhi keberhasilan usaha kecil dan menengah pada pengrajin tenun songket di Desa Jinengdalem Kecamatan Buleleng. Faktor motivasi merupakan yang paling dominan mempengaruhi keberhasilan usaha kecil dan menengah pada pengrajin tenun songket di Desa Jinengdalem disebabkan karena motivasi merupakan dorongan kehendak yang menyebabkan seseorang melakukan suatu perbuatan untuk mencapai tujuan tertentu. Motivasi dapat digolongkan menjadi dua yaitu motivasi internal yang berasal dari dalam pribadi seseorang dan motivasi eksternal yang berasal dari luar pribadi seseorang seperti lingkungan sekitar. Tetapi motivasi yang paling baik adalah yang berasal dari diri sendiri karena dilakukan tanpa paksaan. Dalam menjalani sebuah usaha adanya motivasi sangat penting karena dengan motivasi yang baik maka pengrajin dapat lebih terpacu untuk meningkatkan produksi ataupun kualitas produknya.

Usia merupakan faktor dominan mempengaruhi keberhasilan usaha karena usia seseorang sangat berpengaruh dalam menjalankan usahanya. semakin tinggi usia seseorang, maka semakin bertambah pula ilmu atau pengetahuan yang dimiliki. Usia seseorang dapat menentukan keberhasilan dalam melakukan suatu pekerjaan. Pengrajin tenun songket di Desa Jinengdalem mayoritas berada pada usia produktif, dimana pada usia produktif kinerja dan semangat yang dimiliki seseorang cenderung tinggi dan daya tahan fisik yang 
kuat sehingga dapat menjalankan usahanya dengan maksimal.

\section{SIMPULAN DAN SARAN SIMPULAN}

Berdasarkan hasil analisis data dan pembahasan, maka dapat ditarik kesimpulan yaitu, (1) faktor-faktor yang mempengaruhi keberhasilan usaha kecil dan menengah pada pengrajin tenun songket di Desa Jinengdalem Kecamatan Buleleng adalah (a) faktor motivasi dengan nilai variance sebesar 49,106\%, (b) faktor usia dengan nilai variance sebesar $27,430 \%$, (c) faktor pengalaman dengan nilai variance sebesar $17,705 \%$, (d) faktor pendidikan dengan nilai variance sebesar $9,758 \%$. (2) Faktor yang paling dominan mempengaruhi keberhasilan usaha kecil dan menengah pada pengrajin tenun songket di Desa Jinengdalem Kecamatan Buleleng adalah faktor motivasi dengan nilai varimax rotation $49,106 \%$.

\section{SARAN}

Berdasarkan pembahasan dan simpulan dari hasil penelitian ini, maka dapat diajukan beberapa saran sebagai berikut.

Bagi Pengrajin yang berhasil diharapkan dapat mempertahankan keberhasilan yang dimiliki sekarang, bagi pengrajin yang belum berhasil diharapkan dengan penelitian ini dapat memberikan sumbangan pemikiran agar memperhatikan faktor-faktor yang mempengaruhi dalam keberhasilan usaha. Dan para pengrajin diharapkan dapat mempertahankan dan mewariskan usaha tenun songket ke generasi berikutnya serta meningkatkan kualitas produk, eksistensi dan kepercayaan pasar. Memanfaatkan berbagai peluang yang ada untuk mengembangkan usaha seperti mengikuti berbagai pelatihan dan pameran agar dapat dikenal lebih luas.

Bagi peneliti lain yang berminat untuk mendalami bidang Kewirausahaan terkait dengan keberhasilan usaha disarankan untuk mengembangkan penelitian ini dengan mengembangkan metode yang sama pada jenis usaha yang berbeda. Hal ini berguna untuk menguji keberlakuan temuan faktor-faktor yang mempengaruhi keberhasilan usaha agar hasilnya lebih maksimal.

\section{DAFTAR PUSTAKA}

Andrew, E Sikula. 2000. Manajemen Sumber Daya Manusia. Bandung: Erlangga.

Arikunto. 2006. Prosedur Penelitian Suatu Pendekatan Praktik. Jakarta: Rineka Cipta.

Alma, Buchari. 2007. Kewirausahaan untuk Mahasiswa Umum. Bandung: Alfabeta

Amron. 2009. Manajemen Pemasaran: Surety Bonds. Cetakan Pertama. Jakarta: PT. Bumi Aksara

Basrowi. 2011. Kewirausahaan untuk Perguruan Tinggi. Bogor: PT. Ghalia Indonesia.

Denny, Kushadiyanto. 2006. Analisis Faktor - Faktor yang Mempengaruhi Keberhasilan Pedagang Handphone di Kota Solo (Studi Kasus Pedagang Handphone di Kota Solo). Skripsi (tidak diterbitkan) Universitas Sebelas Maret.

Erliah. 2007. Pengaruh Persaingan, Promosi, dan Keunikan Produk Terhadap Keberhasilan Usaha. Skripsi (tidak diterbitkan) FPIPS UPI Bandung.

Ghozali, Imam. 2006. Aplikasi Analisis Multivariate dengan Program SPSS. Cetakan keempat. Semarang: Badan Penerbit Universitas Diponegoro.

Hafsah, Mohammad Jafar. 2000. Kemitraan Usaha, Konsepsi dan Strategi. Jakarta. Pustaka Sinar Harapan.

Handoko, T Hani. 2004. Manajemen Personalia dan Sumber Daya Manusia. Yogyakarta: BPFE Yogyakarta.

Hasibuan. 2005. Manajemen Sumber Daya Manusia Dasar dari Kunci Keberhasilan. Jakarta: CV. Haji Masagung. 
Hasbullah. 2009. Dasar - Dasar IImu Pendidikan. Jakarta: Grasindo.

Hendro, MM. 2011. Dasar - Dasar Kewirausahaan Panduan Bagi Mahasiswa untuk Mengenal, Memahami, dan Memasuki Dunia Bisnis. Jakarta: Erlangga.

Moekijad. 1992. Latihan dan Pengembangan Sumber Daya Manusia. Bandung: CV. Mandar Maju

Noor, Henry Faizal. 2007. Ekonomi Manajerial. Jakarta: PT. Raja Grafindo Persada.

Notoatmodjo, Soekidjo. 2003. Pendidikan dan perilaku Kesehatan. Jakata: Rineka Cipta.

Payaman, J Simanjuntak. 2005. Pengantar Ekonomi Sumber Daya Manusia. Jakarta. FE UI

Primiana, Ina. 2009. Menggerakkan Sektor Riil UKM dan Industri. Bandung: Alfabeta.

Pratomo, Titik Sartika. 2004. Ekonomi Skala Kecil atau Menengah dan Koperasi. Jakarta: Ghalia Indonesia.

Rahmana, Arief. 2008. Usaha Kecil dan Menengah (UKM), Informasi Terdepan tentang Usaha Kecil dan Menengah.

http://infoukm.wordpress.com. (diakses 4 desember 2016)

Riyanti, Benedicta Prihatin Dwi. 2003. Kewirausahaan dari Sudut Pandang Psikologi Kepribadian. Jakarta: Grasindo.

Siregar, Sofyan. 2010. Statistika Deskriptif untuk Penelitian. Jakarta: Rajawali Press.

Singarimbun, Masri dan Sofian Effendi. 2007. Metode Penelitian Survei. Jakarta: PT Pustaka LP3ES
Sondang, P Siagian. 2001. Manajemen Sumber Daya Manusia. Jakarta. Bumi Aksara

Sugiyono. 2010. Metode Penelitian Pendidikan (Pendekatan Kuantitatif, Kualitatif, dan R\&D). Bandung: ALFABETA.

Suryana. 2011. Kewirausahaan. Jakarta: Salemba Empat.

Suarmawan, Kadek Agus. 2015. Analisis Faktor - Faktor Yang Mempengaruhi Keberhasilan Usaha (Studi pada Pengerajin Bokor di Desa Bulian). Skripsi (tidak diterbitkan) Universitas Pendidikan Ganesha.

Tambunan, Tulus. 2009. UMKM di Indonesia. Bogor. Ghalia.

Tohar, M. 2001. Membuka Usaha Kecil. Yogyakarta: Kanisius.

Umar, Husein. 2005. Metode Penelitian. Jakarta: Salemba Empat.

Undang - Undang Republik Indonesia No. 20 Tahun 2008 Tentang Usaha Mikro Kecil dan Menengah.

Undang - Undang Republik Indonesia Nomor 20 Tahun 2003 tentang Sistem Pendidikan Nasional.

Werther, William B, dan Keith Davis. 2003. Human Resource and Personel Management Fifth Edition. New York: MC Graw Hill Inc.

Widodo. 2015. Manajemen Pengembangan Sumber Daya Manusia. Yogyakarta: Pustaka Pelajar.

Winardi. 2001. Motivasi dan Pemotivasian dalam Manajemen. Jakarta. PT. Raja Grafindo Perkasa 